Saeeda Shab 79

\title{
Female Under-representation in Educational Management
}

\section{Saeeda Shah"}

The obvious fact of female under-representation in educational management across cultures and nations is mentioned in every relevant study. Interestingly this phenomenon transcends the dichotomies such as developed/under-developed, Eastern/Western, Muslim/non-Muslim, First/ Third World countries. Variations are more often due to situational differences. For example, the percentage of female representation in higher education management for the U.S., Britain and China as given by Lyn Davies is respectively 24, 13, and 26 per cent (1992-6; Also see Coleman: 1996), 20-30 per cent in Pakistan (Ibid:4). These statistics could be misleading for generalisation purposes if it is assumed that a higher percentage means more educated women or less gender discrimination. We know that a comparatively higher percentage of women managers in Pakistan is because of 'women only' institutions. In the contexts where management jobs are open to men and women, women are in extremely low numbers, and the situation is not very different in other countries.

This paper examines the socio-cultural barriers to female participation in management - in positions of power and authority. There is no denying the existence of structural and professional deterrents for aspiring and ambitious women, but the argument is that no laws can enforce equality and social justice unless equality is socially acknowledged and practised. The significance of how gender is conceived, perceived and culturally represented cannot be ignored in perpetuating structures in spite of all efforts towards resistance (Skeggs:1991).

\section{An Overview}

\section{Over time and across cultures}

In diverse societies and cultures such as the U.S. (Ozga: 1994), India (Nayyer: 1985), New Zealand (Strachen: 1993), Britain (Wilson: 1995; Wilson: 1997), and many Third World countries (Davies: 1992), different social, organisational, structural, economic and political factors act at different levels as barriers to female participation in management. But common to all societies seems to be an implicit belief that male/female differences compulsively imply female inferiority. It is the socio-historical

\footnotetext{
* Dr. Saeeda Shah has a Ph.D. in education from the UK. She is currently the Dean, College of Home-Economics, Mirpur, Azad Kashmir.
} 
development of the sex-roles and image of women, and its dissemination through different channels throughout human history that lies behind today's marginalised, less motivated, less ambitious, low aspirant woman (Balkin: 1987; Dealmont: 1980).

Interestingly, religions (Islam, Christianity, as well as Hinduism and many others) have also been manipulated to perpetuate female marginalisation and suppression. Delving into that debate is beyond the scope of this brief paper, but one point worth making is that Islam does not perceive one sex superior to the other any more than one person or one race or one tribe from the other, except for their taqwa. The Quran clearly states:

"O mankind, we have created you male and female, and have made you races and tribes, that you may know one another" (49:13).

And the stance adopted by the Muslim women scholars (Ahmed: 1992; A1-Hibri: 1982; Al-Saadawi: 1982; Hussain: 1984; Mernissi: 1991; 1993), and as often supported by non-Muslim women writers (Schimmel: 1978, 1982; Waddy: 1980; Stowasser: 1994), is that Islam and the Quran do not establish any inherent spiritual, intellectual, or physical inferiority of women. Even scholars such as Maulana Maududi who have certain reservations and argue that the female "sphere of activity is the home" (1979:152), recognise women's physical and mental equality and acquisition of knowledge (1979:113-122; also 1995).

However, 'his/story' has presented woman as weak, fallible and inferior, responsible for the fall of Adam from day one. In theology, the first woman is presented as a weak counterpart, who succumbed to Satan's persuasions and caused Adam's expulsion from Eden. This ignores explicit Quranic statements such as "Satan made them both slip from the Garden and so deprived them of their previous felicity" (the Quran:2:36-37, also see Badawi: 1994). And pragmatically, Adam's rushing into a faulty and hasty judgment reflects rather negatively on male decision making -a vital function in management.

Historically, women have been socialised into secondary positions and subordination. The technologies (Foucault: 1977) have at times been social norms, cultural patterns, code of behaviour or even law. In the Greek city states, the first upholders of democracy and human rights, women had no right to vote, which was a negation of their existence as individuals and citizens. Romans, with all their ground set of laws, treated women as merely decorative, bestowing all power to the male head of the family (Massey: 
1988). Aristotle claimed that 'women are physically, mentally and socially inferior to men'. Certain Arab tribes of the early 7th century (pre-Islam) buried their daughters alive at birth. In today's India, Pakistan and Bangladesh, in families of particular socio-economic backgrounds, sympathies are offered at the birth of a female child to the 'unhappy family'. The miserable mother is blamed for bringing the unwanted child into the world and if the number of female offspring increases with no male child to brighten the house, the unlucky mother can be divorced. If economic constraints force a choice, the female child will be the one chosen to not receive an education (Shah: 1986). These attitudes marginalise female children from a very early and impressionistic age.

This socio-historical specification of sex-roles is further emphasised through folk-lore, literature, curricula and the media. Women in Greek literature are there to please, to obey, and to serve. Women in Homer's Odysseus are exchanged, given as prizes, stolen, sold as slaves (Paradotto and Sullivan: 1984). In the later literature, European or Oriental, the favourite female type is the gentle, caring, undemanding woman, quick to serve, willing to obey, and ready to sacrifice. Ibsen's woman becomes controversial by trying to manage the situation herself (The Doll's House). She invites criticism and opposition, becomes an out-cast, and 'the doll's house' crumbles. Perhaps many women suppress their job ambitions or restrict their professional participation to save their 'dolls houses' and this applies to diverse societies.

\section{Barriers or 'Technologies' of Marginalisation}

Acknowledging barriers to the female struggle for equal participation can help the move from the margins to the centre. Gathered from an indepth review of international literature, there emerge three major sets of assumptions leading to female under-representation in educational management and leadership positions:

- Sex-roles: including career mapping, attitude to promotion, female sex-roles, role discrimination, etc.

- Organisational constraints: sexual division of labour inside the institutions, discrimination in promotion, concepts of leadership, etc.

- Power relations within society: networking, role models, etc.

Women and men are different but this difference does not imply a superior/inferior relationship. Strategies need to be developed to take women out of this socio-psychological suppression. Within the sexes 
individuals can outperform in certain areas if they are rightly motivated and developed. The wide spread undervaluation of women's work on the part of governments, planners, academics and others (Brydon and Chant: 1989), their invisibility from planning and decision making (Davies: 1992), a general scarcity of role models/mentors, and hindrances in networking are some major obstacles in changing women's attitude towards opting for management responsibilities.

The sex-roles, stereotyping and career-mapping of women emerge as strong barriers to female entry into positions which have traditionally been associated with men, particularly in management positions (Davies:1987; Evetts: 1994; Ozga: 1994; Kelleyand Elliot: 1982; Sakeshaft: 1991; 1993). Role-socialisation of women (Shakeshaft: 1991; Hall: 1993), reinforced by male cultural domination and the tendency of putting more value on male tasks (Shakeshaft: 1991:94) subjects women to a predetermined devaluation of their contribution to work. Many women scholars have critiqued these attitudes. Al-Khalifa mentions theories of overt and covert discrimination (1992:101; Also Adler et. al. 1993:25; and Ozga: 1994:38) as barriers to management positions. She notes that the association of masculinity, male authority and school leadership is pervasive in the life of the school and argues that educational management is seen as demanding male skills. What Hall calls the 'traditionally gendered organisational roles' (1994:3), and Evetts defines as 'the gendering of careers' (1994:7), is a phenomenon acknowledged by any study of leadership which includes gender. Al-Khalifa discerns an association between theories of organisational leadership and masculinity which deter women from identifying with the role of manager. She emphasises that alternative models of career need to be accompanied by a reconceptualisation of management to include women's experiences and interpretation (1992; also Hall: 1993:30,35). Shakeshaft considers the theories of organisational constraints leading to a lack of role models and networks for women, stereotyping, and male dominated selection committees (1991:67). Marianne Coleman adds to the debate through theories of inequality, referring also to male domination of research methods and management theory as another explanation of female underrepresentation in educational management (1994:187-8).

Davies (1992) maintains that many factors considered as barriers in developed societies are not barriers in the Third World, which indicates a variety of contexts. In certain contexts, women's career mapping appears to be effected by motherhood issues and responsibilities of looking after a family. Men in management have helpful partners to look after the family, while women by entering into management posts add to their responsibilities and work-load. Many women leave work during child-rearing 
or because of other family responsibilities (Ozga: 1994; Riches: 1990; Shakeshaft; 1991; 1993), and a later re-entry into a job may decrease motivation and the opportunity to progress. Marshall comments on the stress to manage their multiple roles and hints meaningfully that "the real problems started after maternity leave" (1984:188). However, women in Pakistan, India, Bangladesh, Sri Lanka and may be in many other Third World countries, which have joint family systems or different social structures, and where severe climatic conditions restrict work-hours, women may not have to leave work to rear children. But there is certainly a greater increase in work-load for the women who are, for reasons, unable to get help from inside the family, or cannot hire domestic help, leading to complaints about accommodating/combining home duties and job responsibilities (Raj: 1982). Although child rearing and family duties do not emerge as a very strong barrier in the Third World context as compared to its significance in developed societies, the issue of work-load in the case of demanding jobs such as institutional headship cannot be ignored as a serious barrier.

Another explanation of female under-representation in management is perceived to be female role-socialisation on the 'domestic' site. In the family, the female child is socialised into stereotypical femininity : to be timid, obedient, silent and soft. Interestingly, none of these qualities is associated with attributes of managers or leaders in the main stream definitions evolving from male experience. Davies (1992) explains overrepresentation of men in management as resulting from the male assumption of administrative/management tasks and their 'over-competitive' attitude. She finds that females need to be persuaded to take management responsibilities and constantly examine their leadership abilities. Women emerge as competent as men in many research studies (Shakeshaft: 1991; Davies: 1992), and their opting to stay out of management jobs to some extent is explained by maintaining that they wrongly presume 'the universality of male experience' (Shakeshaft: 1991).

In a situation such as Pakistan where there is a separate area of female management at the college level, women still avoid taking up higher management jobs in mixed-sex settings. Brydon and Chant (1989) offer another argument that "the cultural norms are so strong that women effectively opt out of visibility by going into stricter purdab". This purdah is not necessarily a veil, but a symbolic attitude opting for invisibility and avoiding the 'gaze' (Foucault: 1977). Such behavioural norms can be one explanation of what Nayyar (1985) refers to as 'disabilities of their sex roles'. Although Davies (1992:19) refuses to accept sex role as disabling, but the analysis by her seems to accept sex roles as a restricting imposition. 
Davies (1992) argues that women "underplay" themselves and this is supported by other studies. Different managers in Shakeshaft (1991) describe women as tentative, better listeners, avoid questions, less assertive, convey signals of courtesy, and more inclusive rather than exclusive (See also Shah: 1998). They are generally regarded as less ambitious, lacking in confidence, over emotional, too family-centred or under-achieving (Davies: 1987), which again points to the cultural norms against which women are judged and are also expected to perform.

Another barrier is that in our male-dominated societies, men find it hard to accept women in positions of authority even in a professional context, which suggests home-to-job transferring of role relationships. Male dominance in the domestic setting is replayed in the 'public'. A1-Khalifa quotes a male teacher saying: "It grates me to have a woman in a position of authority over me" arguing that "rejection of women's leadership .... [is] ... a standpoint shared by many men" (1992:101). Aspiring women do not have to fight only against structural barriers but also social patterns and cultural norms.

In a sex-segregated education system, women managers are accepted as a necessity, but the feeling of rejection persists. The practices are accommodated by shifting and patterning organisations within the discourse of the 'family' where women manage like mothers in the family setting, but with little control over policy or resources. This suits patriarchal traditions. Unless the role relationships in the family change or the role relationships in the organisations are conceived as different from those within the family, the rejection of women's leadership by men will continue, particularly in religious societies structured on patriarchal/feudal patterns.

The odds against which a woman performs and the courage, strength and tolerance that she brings to her work needs to be recognised and appreciated, and this emphasises the importance of net-working. Davies considers networking as an important factor towards promotions and considers it one of the reasons of males' over-representation in educational management. Similarly, role-models/mentors serve as positive incentives. She recommends women-only training courses which "provide space for women to articulate, to experiment, to feel unthreatened and not to have to play power games" (1992:109; also A1-Khalifa: 1992). Nevertheless, she does not exclude mixed sex courses, as these represent the reality of the work situation. 
Saeeda Shah 85

\section{Epilogue}

Davies (1992) claims that men 'assume managerial tasks' because they are 'confident', but she does not go into those cultural norms and sociopsychological suppressions of women which socialise men to be 'confident' and women to submit to secondary positions. When and where these cultural norms do not function very strongly, and socio-psychological suppression is countered by strong and encouraging role models/mentors and networking, women compete with confidence for highly responsible management positions; and in Islam we have many examples of such women from its very early history (Shah: 1998). This should motivate and inspire Muslim women to aim and strive for equality in all situations. 


\section{References}

Ahmed, L., 1992. Women and Gender in Islam: Historical Roots of a Modern Debate, Yale University Press.

A1-Hibri, A (ed), 1982. Women and Islam. Oxford, Pergamon Press. Published as a special issue of Women's Studies International Forum: Vol.5, No. 2.

A1-Khalifa, Elizabeth, 1992. 'Management by Halves: Women Teachers and School Management', in Managing Change in Education (eds) Bennett, N; Crawford, $\mathrm{M}$ and Riches, C. London: Paul Chapman and OUP; pp 95-106.

A1-Saadawi, N., 1982. 'Women and Islam', in A1-Hibri (ed): 1982, op cited; pp 193-206.

Badawi, L: 'Islam', in Holm, J with Bowker, J (eds): 1994. Women in Religion. Pinter Publishers: London, New York; pp 84-112.

Balkin, J., 1987. 'Contribution of friends to women's fear of success in college', in Psychological Reports: 61, 1:pp 39-42.

Brydon, L. and Chant, S., 1989. Women in the Third World: Gender Issues in Rural and Urban Areas. Aldershot, Elgar.

Coleman, Marianne, 1996. 'The Management Style of Women Headteachers', in Educational Management and Administration: Vol. 24, No. 2; pp 163-174.

Davies, L. and Gunawardena, C., 1992. Women and men in Educational Management: An International Enquiry. IIEP : Paris.

Davies, L., 1987. 'Gender and the Management of Education in the Third World Countries', in Comparative Education: Vo1. 23, No.1; pp $85-94$.

Evetts, J., 1994. 'Gender and secondary headship', in Evetts, J. (ed): 1994: Women and Career: Themes and issues in advanced industrial societies. Longman, London and New York; pp 157-169.

Foucault, Miche1, 1977. [Surveiller et punir]. Discipline and punish : the birth of the prison / translated from the French by Alan Sheridan. London : Allen Lane. 
Hall, Valerie, 1993. 'Women in educational management : a review of research in Britain', in Women in education management / edited by Janet Ouston. Harlow, Essex, England : Longman; pp 23-46.

Hussain, F., 1984. Muslim Women. Saint Martin's Press: New York.

Ibsen, Henrik. 'A Dolls House', in The Oxford Ibsen ' Translated and edited by James Walter McFarlane and Graham Orton. London, Oxford University Press, 1960-1977. Vol. 5.

Kelly, G.P. and Elliot, C.M., 1982. Women's Education in the Third World: Comparative Perspectives. State University of Newyork, Albany.

Massey, M., 1988. Women in Ancient Greece and Rome. London: Cambridge University Press.

Maududi, S.A.A., 1995. Purdah and the Status of Women in Islam. Islamic Publications Ltd., Lahore: Pakistan.

Maududi, S.A.A., 19795. Birth Control: Its Social, Political. Economic, Moral and Religious Aspects. Translated and edited by Khurshid Ahmad and Misbahul Islam Faruqi. Lahore, Islamic Publications, Pakistan.

Mernissi, F., 1991. Women and Islam: A Historical Enquiry, Basil Blackwell. Oxford.

Mernissi, F., 1993. The Forgotten Queens of Islam. Polity Press, Cambridge.

Nayyer, U., 1985. 'Women in Educational Management in Third World Countries: The Indian Case Study', in Marshall, D and Newton, E (eds): 1985: The Professional Preparation and Development of Educational Administrators in Developing Areas (Proceedings of CCCA/CEASEA Conference, Nipissing University College).

Ozga, J.(ed), 1994. Women in Educational Management. Buckingham, Routledge.

Peradotto, John and Sullivan, J.P.(eds), 1984. Women in the ancient world : the Arethusa papers. Albany, State University of New York Press.

Raj, M.K., 1982. 'Women, Work and Science in India', in Kelly, G.P. and Elliot, C.M.: 1982, op cited; pp 249-263.

Riches, Colin. 'Communication', in Bush, T. and Burnham, W.J. (eds), 1994. The Principals of Educational Management. Longman:EMDU. 
Schimme1, Annemarie, 1978. Mystical dimensions of Islam. Chapel Hill, N.C., University of North Carolina Press.

Schimmel, Annemarie, 1982. 'Women in Mystical Islam' in A1-Hibri (ed): 1982; op cited; pp 145-152.

Shah, Saeeda, 1998. 'Researching the roots ...' in Educating Muslim Girls .... by Kaye Haw with Saeeda Shah; OUP Buckingham, England.

Shah, Saeeda, 1998. Educational Management ..... Ph.D. thesis at the University of Nottingham, England.

Shakeshaft, C.(ed), 1993. Women in educational management in the United States', in Ouston, Janet (ed), 1993. Women in education management. Harlow, Essex, England : Longman; 47-63.

Shakeshaft, C.(ed), 1991. Women in Educational Administration. Newsbury Park, California, Sage Publication.

Skeggs, B., 1991. 'Post-Modernism: What is all the fuss about?' Review Essay in British Journal of Sociology of Education: Vol. 12, No. 2; pp 255267.

Stowasser, B.F., 1994. Women in the Quran: Tradition and Interpretation. New York: Oxford University Press.

Strachen, J., 1993. 'Searching Women in Educational Leadership', in Gender and Education: Vol. 5, 1, pp 71-80.

Waddy, C., 1980. Women in Muslim History. Longman. London and New York.

Wilson, Fiona M., 1995. Organizational behaviour and gender; foreword by Gibson Burrel1. London, McGraw-Hill.

Wilson, Maggie (ed)., 1997. Women in Educational Management: A European Perspective. London, Paul Chapman. 